\title{
Purification and characterization of therapeutic enzyme l-asparaginase from a tropical soil fungal isolate Fusarium culmorum ASP-87
}

\begin{abstract}
L-asparaginase from fungal source finds extensive applications in pharmaceutical and food industries. L-asparaginase is an enzyme that catalyze the hydrolytic cleavage of the amino acid L-asparagine to L-aspartic acid and ammonia. In the present study, L-asparaginase was purified and characterized from the fungus, Fusarium culmorum ASP-87, isolated from tropical soil. The enzyme was purified to homogeneity by ammonium sulfate precipitation, ion exchange followed by gel filtration chromatography, to 14.03 fold with a final specific activity of $16.66 \mathrm{U} / \mathrm{mg}$ of protein with $2.6 \%$ yield recovery. The molecular mass of the enzyme was $90 \mathrm{kDa}$. The purified L-asparaginase had a $\mathrm{pH}$ optimum of 8.0 and a temperature optimum of $40^{\circ} \mathrm{C}$. The enzyme was stable at $\mathrm{pH} 8.0$ and retained $100 \%$ activity up to $24 \mathrm{hrs}$, and at temperature $60^{\circ} \mathrm{C}$ retained $50 \%$ activity for $60 \mathrm{~min}$. The purified enzyme was highly specific to the substrate L-asparagine and the $\mathrm{K}_{\mathrm{m}}$ and $\mathrm{V}_{\max }$ were found to be $3.57 \mathrm{mM}$ and $0.5 \mu \mathrm{mol} / \mathrm{ml} / \mathrm{min}$, respectively. The enzyme was activated by $\mathrm{Mn}^{2+}$ and Tween 80 and inhibited by $\mathrm{Cu}^{2+}$ and EDTA.
\end{abstract}

Keywords: fusarium culmorum asp-87, 1-asparaginase, soil fungi, ion exchange chromatography, gel filtration chromatography
Volume 2 Issue 6 - 2015

\author{
Anil Kumar Meghavarnam, Savitha \\ Janakiraman \\ Department of Microbiology and Biotechnology, Bangalore \\ University, India
}

\begin{abstract}
Correspondence: Savitha Janakiraman, Department of Microbiology and Biotechnology, Bangalore University, Bangalore-560056, Karnataka, India, Tel 0802296|46I, Email drsvtj@yahoo.co.in
\end{abstract}

Received: October 15, 2015 | Published: November 17, 2015

\section{Introduction}

Microbial L-asparaginase is one of the most important industrial enzymes of interest accounting for about $40 \%$ of the total worldwide enzyme sales. ${ }^{1}$ The enzyme L-asparagine amido hydrolase E.C.3.5.1.1 belongs to an amidase group that catalyzes the hydrolysis of the amino acid L-asparagine to L-aspartic acid and ammonia. This enzyme has got much significance in medical field for the treatment of leukemia especially acute lymphoblastic leukemia (ALL) ${ }^{2}$ and also widely used in baking and food industries to reduce the formation of carcinogenic acrylamides in biscuits and in deep fried potato. ${ }^{3,4} \mathrm{~L}$-asparaginase is widely distributed in plants, animals and microorganisms. However, L-asparaginase from microbial sources has gained much attention because of its high productivity. It is extracellular and therefore secreted in to the fermentation medium. Among microbes, this enzyme is produced by bacteria, fungi and actinomycetes. Microbial strains like Escherichia coli, 5 Erwinia caratovora,${ }^{6}$ Pseudomonas aeruginosa, ${ }^{7}$ Streptomyces gulbargensis, ${ }^{8}$ Aspergillus terreus, ${ }^{9}$ Aspergillus niger, ${ }^{10}$ Penicillium brevicompactum, ${ }^{1}$ Cladosporium $\mathrm{sp}^{11}$ are the main source of L-asparaginase. Bacterial L-asparaginase has been reported to cause hypersensitivity leading to allergic reactions and anaphylaxis. ${ }^{12}$ Hence, L-asparaginase from eukaryotic microorganisms is gaining much importance as it is known to have less adverse effects. ${ }^{13}$ The main objective of the present work was to purify and characterize L-asparaginase from Fusarium culmorum ASP-87 isolated from tropical soil and to demonstrate its physio-chemical properties which are indispensible in both fundamental and applied research.

\section{Materials and methods}

\section{Strain and chemicals}

The fungus F. culmorum strain ASP-87 used in this experiment was isolated from tropical soil. Media components used in the experiment were obtained from Hi-media (Mumbai, India). The substrate L-asparagine, DEAE-cellulose and Sephadex G-100 was procured from Sigma (Sigma-Aldrich, USA). All the chemicals were of analytical reagent grade.

\section{Production of L-asparaginase by Fusarium culmorum ASP-87}

The fungal culture was maintained on potato dextrose agar (PDA) slant at $4{ }^{\circ} \mathrm{C}$ and sub cultured on PDA plates, incubated at $30^{\circ} \mathrm{C}$ for 6 days and used as inoculum. The culture medium used for the study was modified Czapek-dox medium containing g/l of, Glucose,2.0; L-asparagine, $10.0 ; \quad \mathrm{KH}_{2} \mathrm{PO}_{4}, 1.52 ; \quad \mathrm{KCL}, 0.52 ; \quad \mathrm{MgSO}_{4} .7 \mathrm{H}_{2} \mathrm{O}, 0.52 ;$ $\mathrm{CuNO}_{3} .3 \mathrm{H}_{2} \mathrm{O}$, trace; $\mathrm{ZnSO}_{4} .7 \mathrm{H}_{2} 0$, trace; $\mathrm{FeSO}_{4} \cdot 7 \mathrm{H}_{2} 0$, trace; $\mathrm{pH} 7.5 .{ }^{14}$ Modified Czapek-dox broth $(200 \mathrm{ml})$ was prepared, sterilized and inoculated with $F$. culmorum ASP-87 spore suspension $\left(10^{6} / \mathrm{ml}\right)$. The cultures were incubated at $30^{\circ} \mathrm{C}$ under shaken condition (120rpm) for 4days.

\section{Assay of L-asparaginase activity}

The activity of L-asparaginase in the culture filtrate was assayed using the method of Imada. ${ }^{15}$ The rate of hydrolysis of L-asparagine was determined by measuring the ammonia released using Nessler's reagent. A mixture of $0.5 \mathrm{ml}$ of enzyme extract, $0.5 \mathrm{ml}$ of $0.04 \mathrm{M}$ L-asparagine, $0.5 \mathrm{ml}$ of $0.05 \mathrm{M}$ Tris- $\mathrm{HCl}$ buffer $(\mathrm{pH} 7.2)$ and $0.5 \mathrm{ml}$ of distilled water was incubated at $37^{\circ} \mathrm{C}$ for $30 \mathrm{~min}$. The reaction was stopped by the addition of $0.5 \mathrm{ml}$ of $1.5 \mathrm{M}$ trichloroacetic acid (TCA). The ammonia released in the supernatant was determined calorimetrically by adding $0.2 \mathrm{ml}$ of Nessler's reagent into tubes containing $0.1 \mathrm{ml}$ of supernatant and $3.7 \mathrm{ml}$ of distilled water and incubated at room temperature for $20 \mathrm{~min}$. The absorbance was read at $450 \mathrm{~nm}$. One international unit (IU) of L-asparaginase activity is defined as the amount of enzyme required to produce $1 \mu \mathrm{mol}$ of ammonia per min under the conditions of the assay. 


\section{Purification of L-asparaginase}

Ammonium sulfate precipitation: A four day old culture filtrate (200ml) of F. culmorum ASP-87 grown in modified Czapek-dox broth was collected after centrifugation at $8000 \mathrm{rpm}$ for $10 \mathrm{~min}$ at $4^{\circ} \mathrm{C}$. All subsequent purification steps were carried out at $4^{\circ} \mathrm{C}$. The crude enzyme was subjected to ammonium sulfate precipitation and the protein precipitate at $80 \%$ salt saturation was allowed to stand overnight. The precipitate was collected by centrifugation at $10,000 \mathrm{rpm}$ for $15 \mathrm{~min}$ and resuspended in $0.01 \mathrm{M}$ Tris- $\mathrm{HCl}$ buffer $(\mathrm{pH}-$ 7.2) and dialyzed overnight against the same buffer.

Ion exchange chromatography: The dialyzed ammonium sulfate fraction was applied to an anion exchange chromatography on DEAE cellulose $(1.5 \times 15 \mathrm{~cm})$ column pre-equilibrated with the Tris- $\mathrm{HCl}$ buffer $(0.01 \mathrm{M} ; \mathrm{pH}$ 7.2). The unbound proteins were washed repeatedly for five times and then eluted with the same buffer containing $\mathrm{NaCl}(1 \mathrm{M})$ by a stepwise gradient at a flow rate of $1 \mathrm{ml} / \mathrm{min}$. Fractions containing L-asparaginase activity were pooled and lyophilized.

Gel filtration chromatography: The lyophilized samples were loaded onto Sephadex G-100 $(1.5 \times 15 \mathrm{~cm})$ column pre-equilibrated with $100 \mathrm{mM}$ phosphate buffer $\mathrm{pH} 7.0$ and eluted with Tris-HCl buffer $(0.01 \mathrm{M}$; pH 7.2). Fractions were collected $(1 \mathrm{ml} /$ tube) and the absorbance of all the fractions was recorded at $280 \mathrm{~nm}$ and active fractions were pooled and concentrated. The purified L-asparaginase was stored at $4^{\circ} \mathrm{C}$ and used for further characterization.

Estimation of protein: The concentration of protein was estimated by the method of Bradford ${ }^{16}$ using bovine serum albumin as the standard.

Determination of molecular weight of purified protein by SDSPAGE: The molecular weight of purified L-asparaginase was determined by (SDS-PAGE) the method of Laemmli. ${ }^{17}$ SDS-PAGE was performed using a $12 \%$ polyacrylamide gel. The proteins were stained with coomassie brilliant blue R-250. The molecular weight of purified enzyme was determined using standard molecular weight markers (Bio-Rad)

\section{Enzyme characterization}

Effect of pH on enzyme activity and stability: In order to determine the effect of $\mathrm{pH}$ on purified L-asparaginase, the purified enzyme was pre-incubated in $0.1 \mathrm{M}$ buffer in the range between $\mathrm{pH} 3$ and $\mathrm{pH} 11$ without the addition of substrate, the enzyme activity was determined under standard assay conditions. Buffers used were sodium phosphatecitrate $(\mathrm{pH} 3.0-6.0)$, tris- $\mathrm{HCl}(\mathrm{pH} 7.0-9.0)$ and glycine- $\mathrm{NaOH}(\mathrm{pH}$ $10.0-11.0$ ). In order to determine the $\mathrm{pH}$ stability, the purified enzyme was pre-incubated in $\mathrm{pH}$ buffer range between $\mathrm{pH} 3$ and $\mathrm{pH} 11$ at room temperature for $24 \mathrm{hrs}$. The residual activity was determined for every $12 \mathrm{hrs}$ intervals under standard assay conditions. The activity of the enzyme at zero minute of the reaction was considered as $100 \%$ and served as control.

Effect of temperature on enzyme activity and stability: In order to determine the effect of temperature on purified L-asparaginase, the enzyme activity was studied at different temperatures ranging from $20^{\circ} \mathrm{C}$ to $80^{\circ} \mathrm{C}$ at $5^{\circ} \mathrm{C}$ increments, the enzyme activity was determined under standard assay conditions. Thermal stability of the purified enzyme was evaluated by incubating the enzyme for 10, 20,30, 40, 50, 60 minutes at different temperatures ranging from $30^{\circ} \mathrm{C}$ to $80^{\circ} \mathrm{C}$. The residual activity was determined under standard assay conditions. The activity of the enzyme at zero minute of the reaction was considered as $100 \%$ and served as control.
Effect of metal ions, inhibitors and surfactants on L-asparaginase activity: In order to determine the effect of metal ions, inhibitors and surfactants like $\mathrm{Mn}^{2+}, \mathrm{Zn}^{2+}, \mathrm{Fe}^{2+}, \mathrm{Cu}^{2+}, \mathrm{Mg}^{2+}, \mathrm{Ca}^{2+}, \mathrm{Hg}^{2+}, \mathrm{Co}^{2+}, \mathrm{Fe}^{3+}$, EDTA, $\beta$-mercaptoethanol, tween 80 and SDS on L-asparaginase activity, the purified enzyme was preincubated with different metal solutions at $5 \mathrm{mM}$ concentration and inhibitors and surfactants at $1 \mathrm{mM}$ concentration for $30 \mathrm{~min}$ and the residual activity of the enzyme was assessed. The activity of the enzyme without the addition of metal ions or inhibitors or surfactants was considered as $100 \%$ and served as control.

\section{Substrate specificity}

To assess the activity of L-asparaginase, different substrates such as L-asparagine, L-aspartic acid, L-glutamine and L-glutamic acid were used. The substrates were prepared in $0.05 \mathrm{M}$ tris- $\mathrm{HCl}$ buffer $\mathrm{pH}-7.5$ at $10 \mathrm{mM}$ concentration. The enzyme was mixed with substrate and the reaction mixture was incubated for $30 \mathrm{~min}$ at $40^{\circ} \mathrm{C}$ and enzyme activity was determined. Results were expressed as relative percentage.

\section{Determination of kinetic constants}

The kinetic parameters $\mathrm{K}_{\mathrm{m}}$ and $\mathrm{V}_{\max }$ of purified L-asparaginase were determined by the method of Lineweaver and Burk ${ }^{18}$ with different concentrations of L-asparagine (1Mm-10mM) dissolved in $0.05 \mathrm{M}$ of tris- $\mathrm{HCl}$ buffer $\mathrm{pH} 8.0$. The enzyme activity was determined by measuring the rate of hydrolysis of L-asparagine under standard assay conditions.

\section{Results and discussion \\ Purification of L-asparaginase}

The enzyme L-asparaginase was purified from the culture filtrate of $F$. culmorum ASP-87 using ammonium sulfate precipitation, ion exchange chromatography followed by gel filtration. The purification procedure is summarized in (Table 1). The first step of purification by ammonium sulfate precipitation achieved 2.63 -fold purification with $26 \%$ enzyme recovery. The second purification step was done by ion exchange chromatography using DEAE cellulose. This step showed 8.42 -fold increase in enzyme activity with $6.57 \%$ enzyme recovery. The final step of purification was performed by gel filtration using Sephadex G-100 column. The fractions showing L-asparaginase activity in this step were collected and pooled. The final step of purification resulted in 14.03-fold increase in enzyme activity with overall specific activity of $16.66 \mathrm{U} / \mathrm{mg}$ of protein and with a net yield of $2.6 \%$ enzyme recovery. L-asparaginase from various fungal species have been purified and characterized and reported earlier. L-asparaginase from Penicillium brevicompactum NRC 829 was purified to 151.12 fold with a specific activity of $574.24 \mathrm{U} / \mathrm{mg}$ and yield of $39.90 \%{ }^{1}$ and L-asparaginase purified from Mucor hiemalis exhibited a specific activity $69 \mathrm{U} / \mathrm{mg}$ with $18.46 \%$ recovery and 4.59 purification fold. ${ }^{19}$ Interestingly, L-asparaginase from Cladosporium sp was purified to 867.7 fold with a specific activity of $83.8 \mathrm{U} / \mathrm{mg} .{ }^{11}$ Although, the purification steps followed by various researchers are almost similar for different fungal species, the purification fold and yield varies. This could be due to the interference of different proteins present in the culture filtrate.

\section{Physio-chemical characterization of the enzyme L-asparaginase}

Determination of Molecular weight: The purified L-asparaginase 
from F. culmorum ASP-87 showed homogeneity and the molecular mass was estimated as $90 \mathrm{kDa}$, by SDS-PAGE analysis (Figure 1). The molecular weight of L-asparaginase from F. culmorum ASP-87 was almost similar to that of Penicillium brevicompactum NRC 829 $(94 \mathrm{kDa})$ and Trichoderma viride $(99 \mathrm{kDa}) .{ }^{1,20}$ Whereas, L-asparaginase from Cladosporium $s p$ has a molecular weight of $117 \mathrm{kDa}$ and Aspergillus niger with $48 \mathrm{kDa}^{13,21}$ The variability in the molecular weight of L-asparaginase in different organisms may be inferable to its genetic diversities.

Table I Purification of L-asparaginase from F. culmorum ASP-87

\begin{tabular}{|c|c|c|c|c|c|}
\hline Sample & Total enzyme activity (U) & Total protein (Mg) & Specific activity (U/Mg) & Purification fold & Yield (\%) \\
\hline Crude & 95 & 80 & I. 1875 & 0 & 100 \\
\hline $\begin{array}{l}\text { Ammonium sulfate } \\
\text { precipitation }\end{array}$ & 25 & 8 & 3.125 & 2.6315 & 26 \\
\hline lon exchange & 6.25 & 0.625 & 10 & 8.421 & 6.578 \\
\hline Gel filtration & 2.5 & 0.15 & 16.666 & 14.034 & 2.631 \\
\hline
\end{tabular}

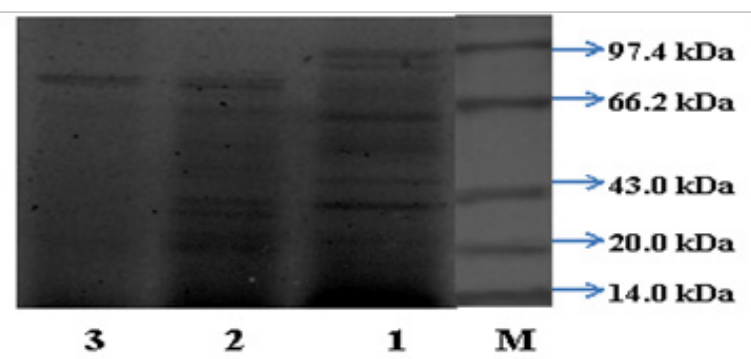

Figure I SDS-PAGE analysis of purified L-asparaginase from F. culmorum ASP-87. M-molecular markers, I- Crude preparation, 2- Ammonium sulfate precipitated protein, 3- Purified protein.

Effect of pH on enzyme activity and stability: $\mathrm{pH}$ is a critical factor for stability and activity of purified enzyme, as it impacts on the ionic form of the enzyme active site residues. The effect of $\mathrm{pH}$ on the activity of purified L-asparaginase was done over a wide range of $\mathrm{pH}$ from 3.0 to 11.0 at $30^{\circ} \mathrm{C}$. The results revealed that L-asparaginase from F. culmorum ASP-87 was active over a broad range of $\mathrm{pH}$, optimum being $\mathrm{pH} 8.0$ (Figure 2). Comparable results were reported by earlier workers in Penicillium brevicompactum NRC $829^{1}$ and Streptomyces sp..$^{22}$ But, on the contrary Lincoln and Monica reported that $\mathrm{pH} 7.0$ was the optimum $\mathrm{pH}$ for the activity of L-asparaginase in Trichoderma viride and Mucor hiemalis. ${ }^{19,20}$ The purified L-asparaginase retained $100 \%$ activity at $\mathrm{pH} 8.0$ up to $24 \mathrm{hrs}$ of incubation (Figure 3). However, L-asparaginase from Trichoderma viride retained $82 \%$ of its activity after $24 \mathrm{hrs}$ of incubation ${ }^{20}$ and Mucor hiemalis maintained its stability only for $4 \mathrm{hrs}$ there after started declining. ${ }^{19}$ The stability of L-asparaginase from F. culmorum ASP-87 at alkaline $\mathrm{pH}$ is a promising factor to be used as a therapeutic agent.

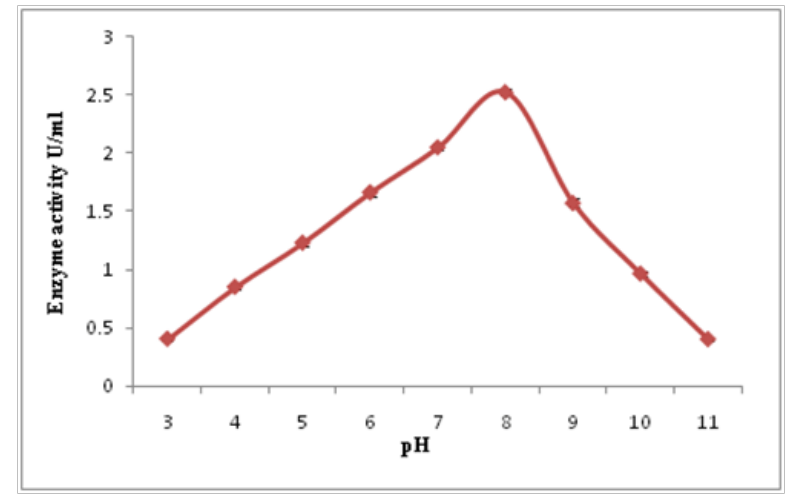

Figure 2 Effect of $\mathrm{pH}$ on the activity of purified L-asparaginase from $\mathrm{F}$. culmorum ASP-87.

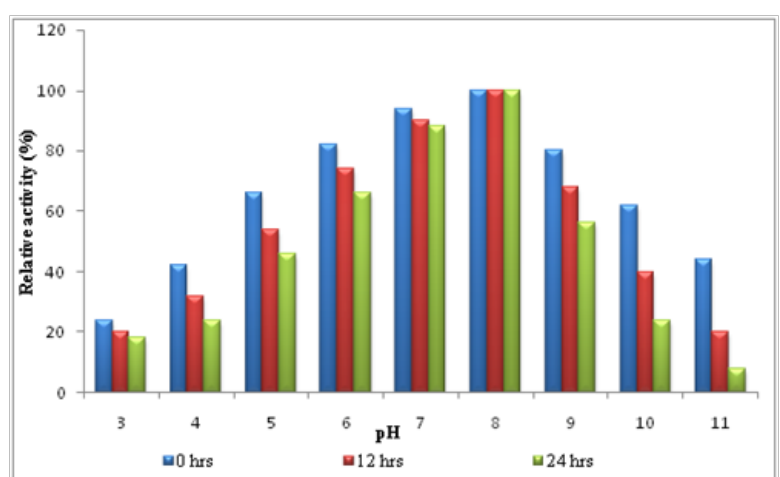

Figure 3 Effect of $\mathrm{pH}$ on stability of purified L-asparaginase from F. culmorum ASP-87.

Effect of temperature on enzyme activity and stability: Temperature is an important physical parameter which influences the enzyme activity. Effect of temperature on purified L-asparaginase was studied over a broad range of temperature from $30^{\circ} \mathrm{C}$ to $80^{\circ} \mathrm{C}$. The optimum temperature for L-asparaginase activity was $40^{\circ} \mathrm{C}$ (Figure 4). However, further increase in temperature, declined the reaction rate sharply. Similar such results were reported by earlier workers in Aspergillus nidulans ${ }^{23}$ and Streptomyces griseoluteus. ${ }^{24}$ But, on the contrary Lincoln, Monica, Elshafi and Abraham reported that $37^{\circ} \mathrm{C}$ was the optimum temperature for the activity of L-asparaginase in Trichoderma viride, Mucor hiemalis, Penicillium brevicompactum NRC 829 and Fusarium sp. ${ }^{1,19,20,25}$ The thermal stability studies of purified L-asparaginase revealed that the enzyme was highly stable for $120 \mathrm{~min}$ at $30^{\circ} \mathrm{C}$ to $40^{\circ} \mathrm{C}$ (Figure 5), but however, inactivated at temperature above $40^{\circ} \mathrm{C}$ while retaining $50 \%$ activity at $60^{\circ} \mathrm{C}$ for 1hour. L-asparaginase from Penicillium brevicompactumNRC 829 was reported to be stable up to 1 hour at $37^{\circ} \mathrm{C} .{ }^{1}$ Considering the thermal stability of other organisms reported earlier, L-asparaginase from F. culmorum ASP-87 shows moderate thermostability, a factor of significant importance in pharmaceutical industry.

Effect of metal ions, inhibitors and surfactants on L-asparaginase activity: The influence of various metal ions on purified L-asparaginase activity was studied. Among the different metal ions tested $\mathrm{Mn} 2+$ enhanced the activity of enzyme by $18 \%$ (Table 2 ) as reported by earlier worker in Mucor hiemalis. ${ }^{19}$ Whereas, $\mathrm{Cu} 2+$ and $\mathrm{Hg} 2+$ inhibited the activity of enzyme by 84 and $80 \%$, as observed by Archana in Aspergillus nidulans ${ }^{23}$ and Kumar in Pectobacterium carotovorum. ${ }^{26}$ However, other metal ions like $\mathrm{Ca} 2+$ and $\mathrm{Mg} 2+$ did not have much effect on enzyme activity. Among the two inhibitors tested, EDTA inhibited the activity by $88 \%$ while $\beta$-mercaptoethanol 
did not have any effect on enzyme activity. ${ }^{20}$ However, Senthil kumar \& Selvam ${ }^{27}$ reported that EDTA act as an inducer in Streptomyces radiopugnans $\mathrm{MS} 1 .{ }^{27}$ Among the surfactants tested, the non ionic surfactant tween 80 was found to enhance the activity of the enzyme by $16 \%$, whereas, the anionic surfactant SDS completely inhibited the enzyme activity. Kumar and Monica also reported similar such finding that tween 80 at $2 \mathrm{mM}$ concentration induced the production of L-asparaginase in Cladosporium sp and Mucor hiemalis. ${ }^{11,19}$

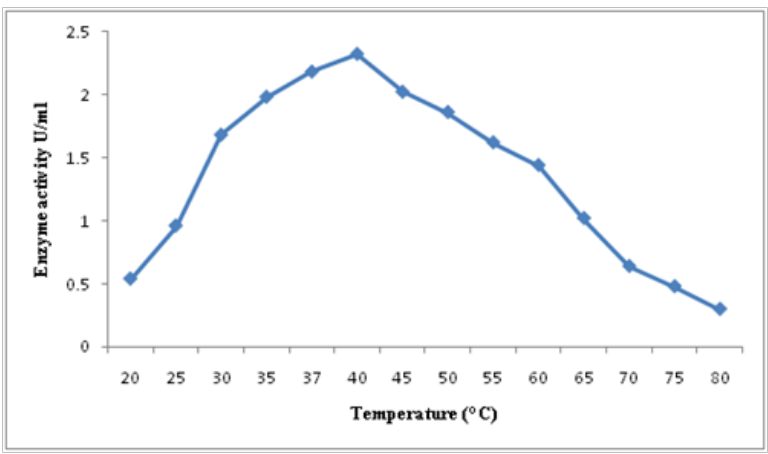

Figure 4 Effect of temperature on the activity of purified L-asparaginase from F. culmorum ASP-87.

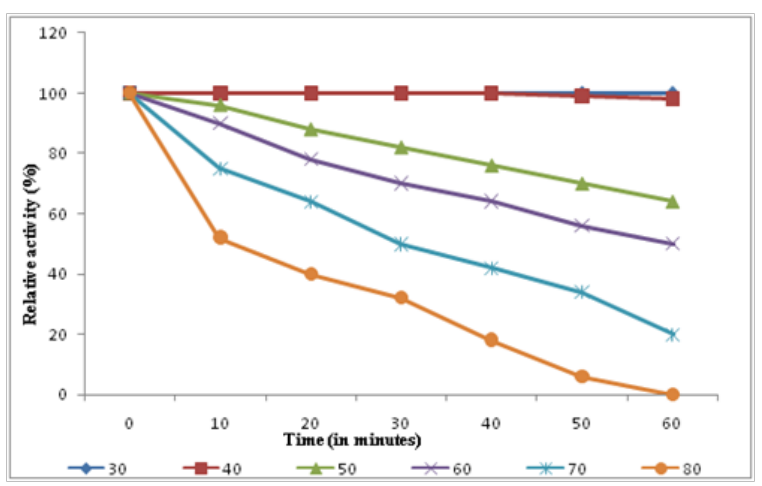

Figure 5 Effect of temperature on stability of purified L-asparaginase from $\mathrm{F}$. culmorum ASP-87.

\section{Substrate specificity}

The property of enzymes that makes them important as diagnostic tools is the specificity they exhibit towards the substrate. Among the different substrates investigated, the enzyme showed high specificity towards its natural substrate L-asparagine, very low specificity towards L-aspartic acid, while no activity towards L-glutamine and L-glutamic acid (Figure 6). Our findings were in concordance with that of Prabhu, Sahira and Lincoln in Vibrio costicola, Acinetobacter baumannii and Trichoderma viride respectively. ${ }^{20,28,29}$ This property of purified enzyme increases its potential to be used in therapeutics and food industries.

\section{Determination of kinetic constants}

The $\mathrm{K}_{\mathrm{m}}$ and $\mathrm{V}_{\max }$ of purified L-asparaginase from $F$. culmorum ASP-87 were determined using various concentrations of $\mathrm{L}$-asparagine. The values of $\mathrm{K}_{\mathrm{m}}$ and $\mathrm{V}_{\max }$ were $3.1 \mathrm{mM}$ and $0.77 \mu \mathrm{mol} /$ $\mathrm{ml} / \mathrm{min}$ respectively (Figure 7) which is lower than the $\mathrm{Km}$ value of L-asparaginase purified from E. coli, Penicillium sp and Mucor hiemalis. ${ }^{19,30,31}$ However, a slightly higher $\mathrm{K}_{\mathrm{m}}$ value of $12.5 \mathrm{mM}$ and lower $\mathrm{K}_{\mathrm{m}}$ value of $1.05 \mathrm{mM}$ were reported in Aspergillus aculeatus and Penicillium brevicompactum. ${ }^{1,32}$ The purified L-asparaginase from Fusarium culmorum ASP-87 has stronger affinity towards its natural substrate L-asparagine, a positive property to be useful towards the treatment of tumors.
Table 2 Effect of metal ions, inhibitors and surfactants on L-asparaginase activity.

\begin{tabular}{ll}
\hline Metal ions (5mm) & Relative activity $(\%)$ \\
\hline Control & 100 \\
$\mathrm{Zn}^{2+}$ & 77 \\
$\mathrm{Fe}^{2+}$ & 68 \\
$\mathrm{Cu}^{2+}$ & 16 \\
$\mathrm{Mg}^{2+}$ & 93 \\
$\mathrm{Ca}^{2+}$ & 96 \\
$\mathrm{Mn}^{2+}$ & 118 \\
$\mathrm{Hg}^{2+}$ & 20 \\
$\mathrm{Co}^{2+}$ & 72 \\
$\mathrm{Fe}^{3+}$ & 59 \\
EDTA & 12 \\
$\beta$-mercaptoethanol & 76 \\
Tween 80 & 116 \\
SDS & 0
\end{tabular}

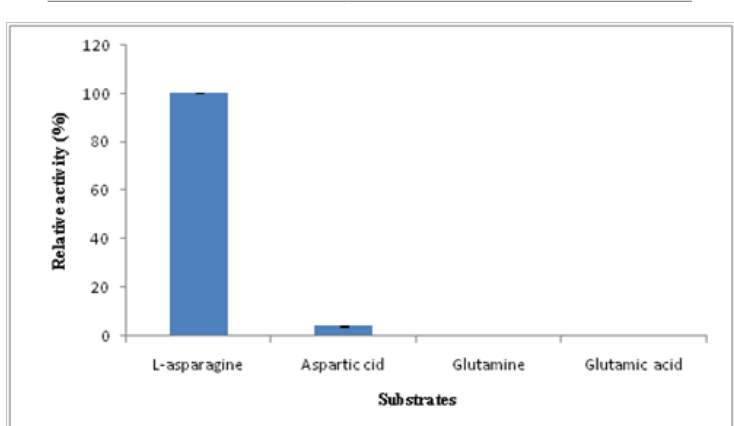

Figure 6 Substrate specificity of purified L-asparaginase from F. culmorum ASP-87 towards various substrates.

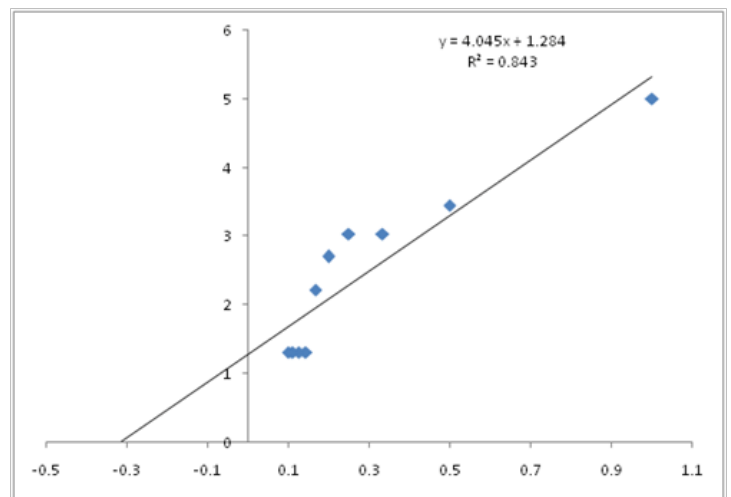

Figure 7 Lineweaver- Burk double reciprocal plot for the determination of $\mathrm{Km}$ and $\mathrm{Vmax}$ of purified L-asparaginase from F. culmorum ASP-87.

\section{Conclusion}

L-asparaginase from microbial source is of great interest owing to its significance in pharmaceutical and food industries. Therefore, in the present study, an attempt is made to purify L-asparaginase from Fusarium culmorum ASP-87 and its physical and chemical characteristics were studied. The stability of L-asparaginase at alkaline $\mathrm{pH}$ and temperature is an advantage for pharmaceutical and food applications. The specificity of L-asparaginase to its natural substrate L-asparagine is of greater importance for making 
diagnostic biosensors. However, further in depth studies are required to optimize cost effective substrate for bulk production of enzymes. Although, a strain of Fusarium culmorum IFO5902 is been reported to possess L-asparaginase activity by Nakahama way back in $1973,{ }^{33}$ no attempt was made so far to purify and characterize the physiochemical nature of the enzyme. This is the first report which gives the complete physical and chemical nature of the purified L-asparaginase from Fusarium culmorum, isolated and identified as one of the best producers of L-asparaginase by dye based rapid screening method among the 364 soil fungal isolates screened. ${ }^{34}$

\section{Acknowledgements}

The author acknowledges Department of Microbiology and Biotechnology, Bangalore University, Bangalore, India, for their kind support.

\section{Conflict of interest}

The author declares no conflict of interest.

\section{References}

1. Elshafei AM, Hassan MM, AbouZeid MA, et al. Purification, characterization and antitumor activity of L-asparaginase from Penicillium brevicompactum NRC 829. Br Microbiol Res. 2012;2(3):158174.

2. Verma NK, Kumar G, Kaur-Anand S. L-asparaginase: A promising chemotherapeutic agent. Crit Rev Biotechnol. 2007;27(1):45-62.

3. Pedreschi F, Kaack K, Granby K. The effect of asparaginase on acrylamide formation in French fries. Food Chem. 2008;109(2):386-392.

4. Mohan Kumar NS, Manonmani HK. Survey on acrylamide in some of the food samples in and around Mysore city: India. Asian J Microb Biotechnol Enviorn Sci. 2012;14(1):149-155.

5. Younes G, Alireza E, Sara RA, et al. An optimized medium for screening of L-asparaginase production by Escherichia coli. Am J Biochem Biotechnol. 2008;4(4):422-424.

6. Vaibhav DD, Mangesh DV, Lambert R. Production of intracellular Lasparaginase from Erwina carotovora and its statistical optimization using response surface method. Int J Chem Sci Appl. 2010;1(1):25-36.

7. Manikandan R, Pratheeba CN, Pankaj S, et al. Optimization of Lasparaginase production by Pseudomonas aeruginosa using experimental methods. Nat Sci. 2010;8(2):1-6.

8. Amena S, Vishalakshi N, Prahhakar M, et al. Production, purification and characterization of $L$ - asparaginase from Streptomyces gulbargensis. Braz J Microbiol. 2010;41(1):173-178.

9. Balasubramanian K, Ambikapathy V, Panneerselvam A. Production, isolation, and purification of L-asparaginase from Aspergillus terreus using submerged fermentation. Int J Adv Pharma Res. 2012;3(2):778783

10. Laan VD, Stor MC, Lange DI, et al. Aspergillus niger asparaginase variants and their commercial uses. US Patent No. WO2008128974. 2008.

11. Kumar NSM, Manonmani HK. Purification, characterization and kinetic properties of extracellular L-asparaginase produced by Cladosporium sp. World J Microbiol Biotechnol. 2013;29(4):577-587.

12. Moola ZB, Scawen MD, Atkinson T, et al. Erwinia chrysanihemi Lasparaginase: epitope mapping and production of antigenically modified enzymes. Biochem J. 1994;302:921-927.

13. Sarquis MIDM, Oliveira EMM, Santos AS, et al. Production of L-asparaginase by filamentous fungi. Mem Inst Oswaldo Cruz. 2004;99(5):489-492.
14. Saxena RK, Sinha U. L-asparaginase and glutaminase activities in the culture filtrates of Aspergillus nidulans. Curr Sci. 1981;50(5):218-219.

15. Imada A, Igarasi S, Nakahama K, et al. Asparaginase and glutaminase activities of micro-organisms. J Gen Microbiol. 1973;76(1):85-99.

16. Bradford MM. A rapid and sensitive method for the quantitation of microgram quantities of protein utilizing the principle of protein-dye binding. Anal Biochem. 1976;72:248-254.

17. Laemmli UK. Cleavage of structural proteins during the assembly of the head of bacteriophage T4. Nature. 1970;227:680-685.

18. Lineweaver H, Burk D. The determination of enzyme dissociation constants. J Am Chem Soc. 1934;56(3):658-666.

19. Monica T, Lynette L, Niyonzima FN, et al. Isolation, purification and characterization of fungal extracellular L-asapraginase from Mucor hiemalis. J Biocat Biotrans. 2013;2:1-9.

20. Lincoln L, Francois N, Niyonzima Sunil SM. Purification and properties of a fungal L-asparaginase from Trichoderma viride pers: SF GREY. $J$ Microbiol Biotechnol Food Sci. 2015;4(4):310-316.

21. Akilandeswari K, Kavitha K, Vijayalakshmi M. Production of bioactive enzyme L-asparaginase from fungal isolates of water sample through submerged fermentation. Int J Pharma Sci. 2012;4(Suppl 4):363-366.

22. El-Sabbagh SM, El-Batanony NH, Salem AT. L-asparaginase produced by Streptomyces strain isolated from Egyptian soil:Purification, characterization and evaluation of its anti-tumor. Afr J Microbiol Res. 2013;7(50):5677-5686.

23. Archana Rani J, Raja Rao P. Production, purification and characterization of L-asparaginase from Aspergillus nidulans by solid substrate fermentation. Eur J Biotechnol Bio. 2014;2(4):51-58.

24. Kamala Kumari PV, Girija Shankar G, Prabhakar T, et al. Purification and characterization of L-asparagianse from Streptomyces griseoluteus WS3/1. Int J Pharma Sci Rev Res. 2013;23(2):198-202.

25. Abraham A, Baliga P. Production, purification and characterization of extracellular L-asparaginase having anti neoplastic activity from Fusarium sp. J Adv Res Biol Sci. 2012;4(4):293-301.

26. Kumar S, Venkata Dasu V, Pakshirajan K. Purification and characterization of glutaminase-free L-asparaginase from Pectobacterium carotovorum MTCC 1428. Bioresour Tech. 2011;102(2):2077-2082.

27. Senthil Kumar M, Selvam K. Isolation and purification of high efficiency L-asparaginase by quantitative preparative continuous-elution SDSPAGE electrophoresis. J Microb Biochem Tech. 2011;3(5):073-083.

28. Prabhu GN, Chandrasekaran M. Purification and characterization of an anti-cancer enzyme produced by marine Vibrio Costicola under a novel solid state fermentation process. Braz Arch Biol Technol. 2000;42:363368 .

29. Sahira NM. Production, purification and characterization of a novel Lasparaginase from Acinetobacter baumannii with anticancerous activity. Int J Curr Eng Tech. 2014;4(1):6-11.

30. Willis RC, Woolfolk R. Asparagine utilization in E. coli. J Bacteriol. 1974; 118(1):231-241.

31. Patro KR, Gupta N. Extraction, purification and characterization of L-asparaginase from Penicillium sp. by submerged fermentation. Int $J$ Biotechnol Mol Bio Res. 2012;3(3):30-34.

32. Dange VU, Peshwe SA. Production, purification and characterization of fungal L-asparaginase. Bionano Frontier. 2011;4:162-167.

33. Nakahama K, Imada A, Igarasi S, et al. Formation of L-asparaginase by Fusarium sp. J Gen Microbiol. 1973;75(2):269-276.

34. Meghavarnam Anil Kumar, Janakiraman Savitha. A simple and efficient dye-based technique for rapid screening of fungi for L-asparaginase production. J Exp Biol Agric Sci. 2015;3(2):123-130. 